\title{
Plenary Session 1:
}

Interactions

Metropolises - Alps

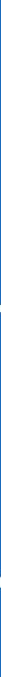




\title{
Introduction
}

\author{
Presentation: Axel Borsdorf
}

During the International Year of the Mountains in 2002, Jack Ives asked for a better recognition and understanding of interactions between highlands and lowlands. In the Alps, a very specific form of interaction takes place between the mountain regions and their forelands, which is characterised by primary production, tourism industry and the absence of metropolisation in the mountains, and metropolises like Munich, Vienna, Milan, Turin, Marseille and Lyon in the forelands.

Session 1 of the ForumAlpinum 2010 will outline the reverse structure of the larger Alpine region and some of the interactions between mountains and lowlands. Mountains play an important role providing ecosystem services (water, energy, fresh air, biodiversity, leisure amenities and more) to the metropolitan population. The peri-Alpine metropolises offer jobs (outside agriculture and tourism), a prime retail trade offer, high quality services, access to the international air traffic and other benefits to the Alpine population. This structure can be complementary and well-balanced, but it can also develop in an unbalanced way that weakens the mountain locations. Regional planning and regional policy are therefore necessary to avoid "Alpine fallows" and to enhance sustainable developments in mountains and lowlands.

Some megatrends are to be observed: The transformation of Alpine regions into suburbs of the peri-Alpine metropolises (Bätzing 2003), the shift of high central functions to the outer-Alpine agglomerations (Perlik 2001), the location of central functions in periurban and former rural areas, which was called post-suburbanisation (Borsdorf 2002), the re-urbanisation, characterised by the reimmigration of parts of the population to the city centres (Haase et al. 2006), the demographical and functional marginalisation of peripherical rural areas, which already were called "Alpine fallows" (Schuler et al. 2004) and the ongoing trend of amenity migration to remote Alpine valleys and mountains (Perlik 2006, Steinicke et al. 2009).

Plenary Session 1 will discuss these trends, which may influence the future development of interactions in the Alpine/peri-Alpine regional system.

\section{References}

Bätzing, W. (2003): Die Alpen. Geschichte und Zukunft einer europäischen Kulturlandschaft. 2. Auflage, C.H. Beck, München.

Borsdorf, A. (2002): On the Way to Post-Suburbia? Changing Structures in the Outskirts of European Cities. In: Borsdorf, A. \& P. Zembri (eds.): Structures. European Cities - Insights on Outskirts. Paris: 7-30.

Haase, A., S. Kabisch \& A. Steinführer (2006): Aufschwung der inneren Stadt in Europa? Reurbanisierung unter den Bedingungen des demographischen Wandels im internationalen Vergleich. Europa Regional 14/4: 167-180.

Perlik, M. (2001): Alpenstädte - zwischen Metropolisation und neuer Eigenständigkeit. Institut für Geographie, Universität Bern, Bern

Perlik, M. (2006): The Specifics of Amenity Migration in the European Alps. In: Moss, L. A. G. (ed.): The Amenity Migrants. Seeking and Sustaining Mountains and their Cultures. CABI, Cambridge UK: 215-231.

Schuler, M., M. Perlik \& N. Pasche (2004): Nicht-städtisch, rural oder peripher - wo steht der ländliche Raum heute? Analyse der Siedlungs- und Wirtschaftsentwicklung in der Schweiz. Bundesamt für Raumentwicklung (ARE), Bern.

Steinicke, E., P. Cede \& U. Fliesser (2009): Development Patterns of Rural Depopulation Areas. Demographic Impacts of Amenity Migration on Italian Peripherical Regions. Mitteilungen der Österreichischen Geographischen Gesellschaft 151: 195-214. 


\title{
The Spatial Tension Between the Alps and the Peri-Alpine Metropolises - a Contradictory Process of the Simultaneity of Non-Simultaneous Developments
}

\author{
Axel Borsdorf
}

The Alps are surrounded by important European metropolises like Vienna, Munich, Zurich, Lyon, Milan, Turin, Ljubljana and more, while only secondary cities - the most important are Grenoble, Innsbruck, Bolzano - are located within the Alpine arc. This disparity of urban development in the Alpine and peri-Alpine regions is related to the process of industrialisation during the 19th and 2oth century, when the Alpine regions lost competitiveness and the locations outside the Alps were favoured by industries because of their better accessibility and the development of high-end transport infrastructure (railroads, motorways, airports).

Thus, Perlik (2001) observed a hierarchy of urban centres within and outside the Alps, in which the peri-Alpine agglomerations enjoy international and even global importance, whereas inner-Alpine urban centres only count with regional or national central functions. Bätzing (2003) went even further, identifying an ongoing process of "suburbanisation" of the Alps, in which the Alpine cities are increasingly turning into suburbs of the peri-Alpine metropolises, fulfilling only complementary functions for the metropolitan centres.
In this process, some Alpine regions completely lose their traditional functions, leading to an overhang of old people, loss of population and marginality. The volume "Mapping the Alps" (Tappeiner et al. 2008) demonstrates the immense disparities within the Alps, where large parts of the French, Italian and Swiss Alps suffer a dramatic rural exodus. The Swiss regional policy labelled these marginal regions "Alpine fallows" (see Schuler et al. 2004), which no longer receive stimulation and subsidies from national funds.

To a certain degree this observation is contradicted by other studies of Borsdorf (2002), who observed the migration of central functions to periurban locations. The new "post-suburbia" emerges in formerly rural areas, not too far from the cities, where malls, urban entertainment centres, service clusters, private universities and leisure infrastructure are developed, making these locations quite attractive even for immigrating residents. They live and work in the new post-suburban centres, source all provision there and might not even need the former central towns any longer.

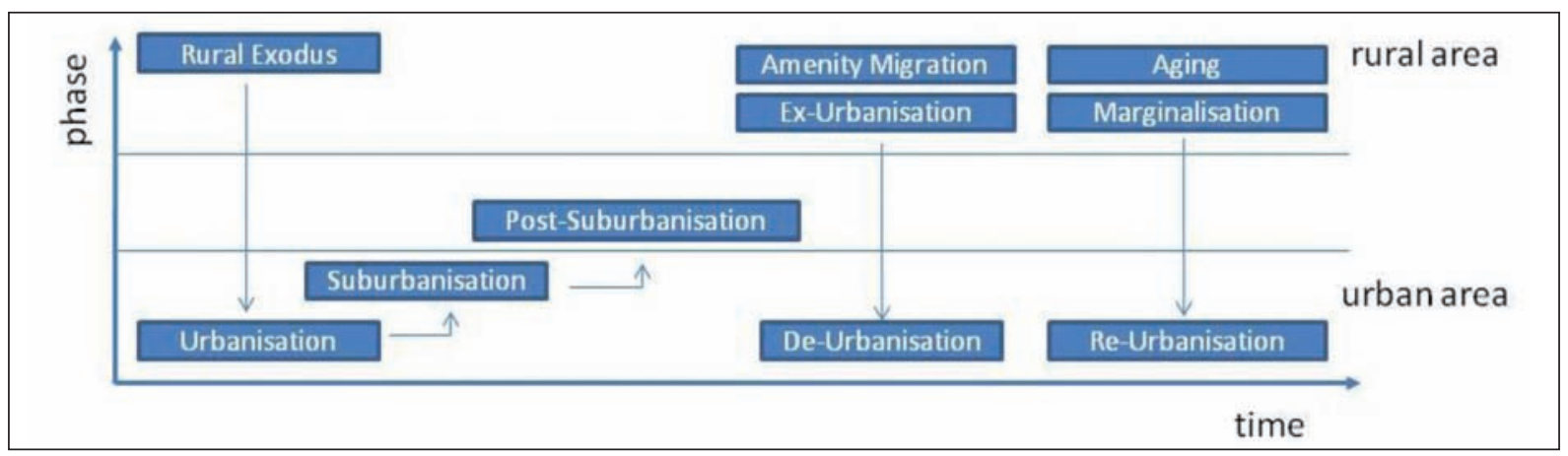

Fig. 1: Processes in the Urban-Rural (Peri-Alpine-Alpine) Continuum, Traditional Interpretation. 
A last development should be mentioned as well, i.e. the trend of "amenity migration" in the search for clean air, a nice environment and authentic cultures (Perlik 2006, Steinicke et al. 2009) in the Alps, repopulating remote valleys and mountains.

Most authors see the rise of suburbia and postsuburbia, followed by processes of de- and exurbanisation, the drive of amenity and lifestyle migration towards the amenity-rich (Alpine) areas, and the remigration of former suburban and post-suburban population and (to a certain degree) of rural populations (followed by demographic losses and aging in remote (Alpine) areas which leads to marginalisation and (Alpine) fallows) as sequential processes in the time-space system (Fig. 1). In contrast to this interpretation, we argue that these trends can be regarded as a contradictory process of the simultaneity of non-simultaneous developments (Bloch 1985). They are contemporary tendencies and processes in the rural-urban compound, and this is also true for the spatial system of Alpine areas and peri-Alpine metropolises (Fig. 2).

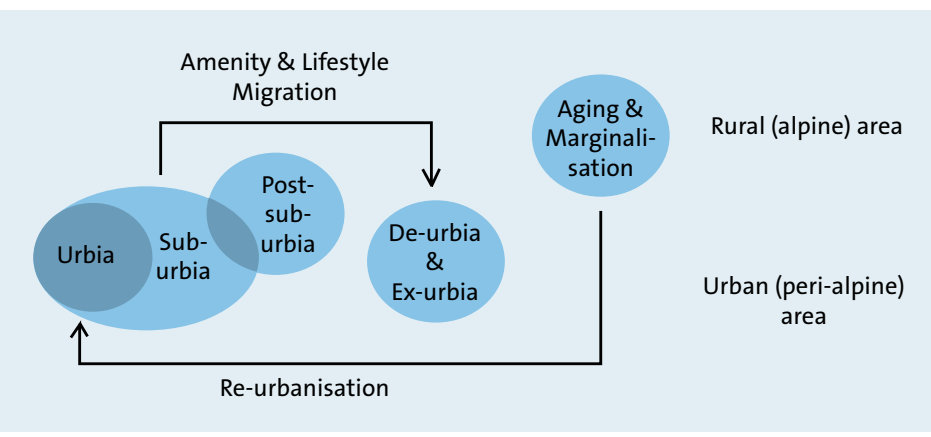

Fig. 2: Contemporary Processes in the Urban-Rural (PeriAlpine-Alpine) Compound.

Global change (climate warming, political, economical, cultural and social globalisation) is an important driver of these developments. They pose a major challenge for regional policies intent on sustainable regional development in the Alpine and peri-Alpine realm. Not only do we need a better analysis of the spatial reorganisation, the causes and consequences, but also innovative adaptation strategies to face the challenges and to implement planning and steering instruments for a better balance in the interaction of peri-Alpine metropolises and remote Alpine areas. As gentrification, amenity migration, and marginalisation are driven by the multiplicity of lifestyles in a post-modern society, steering instruments will be only effective if they include the expectations, wishes and interests of the individual citizens. Participation is still too much orientated on the demands of stakeholders. Innovative methods have to take a closer look at the multiplicity of interests of individuals in order to find satisfactory and sustainable solutions.

\section{References}

Bätzing, W. (2003): Die Alpen. Geschichte und Zukunft einer europäischen Kulturlandschaft. 2. Auflage, C.H. Beck, München.

Bloch, E. (1985): Das Prinzip Hoffnung. Werkausgabe Vol. 5, Suhrkamp, Frankfurt/M.

Borsdorf, A. (2002): On the Way to Post-Suburbia? Changing Structures in the Outskirts of European Cities. In: Borsdorf, A. \& P. Zembri (eds.): Structures. European Cities - Insights on Outskirts. Paris: 7-30.

Haase, A., S. Kabisch \& A. Steinführer (2006): Aufschwung der inneren Stadt in Europa? Reurbanisierung unter den Bedingungen des demographischen Wandels im internationalen Vergleich. Europa Regional 14/4: 167-180.

Perlik, M. (2001): Alpenstädte - zwischen Metropolisation und neuer Eigenständigkeit. Institut für Geographie, Universität Bern, Bern.

Perlik, M. (2006): The Specifics of Amenity Migration in the European Alps. In: Moss, L. A. G. (ed.): The Amenity Migrants. Seeking and Sustaining Mountains and their Cultures. CABI, Cambridge UK: 215-231

Schuler, M., M. Perlik \& N. Pasche (2004): Nicht-städtisch, rural oder peripher - wo steht der ländliche Raum heute? Analyse der Siedlungs- und Wirtschaftsentwicklung in der Schweiz. Bundesamt für Raumentwicklung (ARE), Bern.

Steinicke, E., P. Cede \& U. Fliesser (2009): Development Patterns of Rural Depopulation Areas. Demographic Impacts of Amenity Migration on Italian Peripherical Regions. Mitteilungen der Österreichischen Geographischen Gesellschaft 151: 195-214.

Tappeiner, U., A. Borsdorf \& E. Tasser (eds.) (2008): Mapping the Alps. Alpenatlas. Spektrum Akademischer Verlag, Heidelberg. 


\title{
The Alps - Periurbanisation in a Rural Macro-Region in Europe
}

\author{
Werner Bätzing
}

The Alps - a Peripheral Region with a Low Proportion of Urban Centres

Although the Alps as a European macro-region are located in the heart of Europe, they have long been a peripheral area from an economic, social and political perspective. There are three causes for this situation:

1. As Hans Bobek showed as early as 1928 using the specific example of Innsbruck, the topography of this geologically recent high-mountain range and its vast expanses of wastelands have long presented an obstacle to cities and their catchment areas. This is why, in comparison with the rest of Europe since the Middle Ages, the Alps have been a region with few urban centres.

2. From the early modern period onward, Europe saw the rise of ever larger territorial structures which resulted in national states with fast-growing capital cities. This development put the Alps at a disadvantage as new borders were drawn along the Alps' highest ridges. This political portioning-up of the Alps turned each segment into the peripheral area of a territory whose centre lay far beyond the Alps - the only exception being Switzerland, which retained a pre-modern political structure.

3. Explosive urban growth accompanied Europe's industrial revolution, which put the Alps at a further economic and social disadvantage: firstly, industrialism was slow to reach the Alps (in around 1880 ), and in a relatively weakened form. None of the towns and cities in the Alps experienced the kind of growth of industrialised cities. Even though Alpine cities grew faster than other Alpine communities, their growth was fairly modest and below the European average. Secondly, from 1880 and along with the rise of tourism, which would have been unthinkable without the industrial revolution, a distorted picture of the Alps as a rural idyll emerged all over industrialised Europe, which resulted in a mental block towards and social marginalisation of the Alps.

These are the three reasons why the Alps are a European macro-region with comparatively few, and - in the European context - relatively small cities. Nevertheless, these Alpine cities are much more important than is usually assumed because the false cliché of the Alps tends to overlook urban centres, pretending that the Alps are a region without them.

\section{Current Situation of Cities in the Alpine Region}

In the current situation of highly globalised servicebased societies, the Alps are at a clear disadvantage. It is the received opinion that in a competitive economy connections are very close between the productive and service industries; that innovation relies upon research and development to a high degree; that a creative environment relies upon unplanned and frequent face-to-face encounters; and that highly motivated staff lead urban lives requiring a range of leisure and cultural activities only available in large cities. All of these prerequisites can only be found in very large cities with a lively cultural scene. This is why it is assumed that only "metropolitan regions of European significance" have a competitive, innovative economy.

The Alps are essentially at a disadvantage from these new spatial requirements for service-based societies that began to establish themselves from the 1980 on onards because none of the towns and cities located in the Alps is sufficiently large and active to qualify as a "metropolitan region of Euro- 
pean significance". It is therefore no coincidence that the spatial analysis carried out in the Alps in the context of the EU ESPON programme has not identified a single metropolis. In the Alps there are only six "transnational/national functional urban areas", which is the second type of "European Functional Urban Areas (FUAs)", while they occur very frequently elsewhere in Europe (ESPON 2009, p. 4). This means that the Alps are very clearly to be considered a functionally disadvantaged macro-region in Europe.

Due to their high locational value at the heart of Europe, in particular as part of the so-called "Blue Banana", the Alps nevertheless benefit from Europe's current development: being sandwiched between dynamic metropolitan regions, the Alps can be accessed relatively quickly by relevant portions of the European population via transalpine transport routes (see maps in the Raumordnungsbericht 2005 (2005 Spatial Planning Report) of the German Bundesamt für Bauwesen und Raumordnung/Bonn (Federal Office for Building and Regional Planning/Bonn) and ESPON maps). Also, large metropolises along the Alpine rim are currently growing at a disproportionate rate (except Turin and Geneva), with growth predicted to continue until 2025.

The spatial location of the Alps has led to strong urbanisation processes in the Alps. Four different types can be distinguished:

1. Strong growth in Alpine cities: Easily accessible Alpine cities, often located along international transit routes, are currently showing strong population and economic growth. However, this is due to displacement effects, with national and international businesses pushing out local and regional ones, resulting in a weakening of the Alpine cities' transregional and regional controlling and management functions. In the context of globalisation these locations are under increasing pressure. At the same time, branch offices and affiliations of international companies are moving in. Cities such as Thun, Interlaken or Bad Tölz, which are located along the Alpine rim and in the catchment area of extra-Alpine metropolises, are already undergoing massive restructuring or "suburbanisation"; important residential, leisure and nature conservation functions are being transferred here from the agglomerations. Cities such as Innsbruck, Bolzano or Trient, located in the Alps, however, are as yet less strongly affected by this shift. Alpine cities are nevertheless facing a serious problem in this structural change because, in comparison to extra-Alpine cities, their economic structure already showed some weaknesses in 1990, in that there was a disproportionate overrepresentation of construction, industry and tourism, while research \& development and specialised services were significantly underrepre- sented (Perlik 2001, pp. 95 ff.). Moreover, the topography leads to high real-estate prices due to the scarcity of land suitable for building.

2. Belts of urbanisation along transit routes: For the past twenty years or more, along transit routes (motorways), increasing numbers of industrial estates have been built on wide valley floors in the vicinity of motorway exits. These estates tend to produce a continuous housing belt (easily identifiable on Corine Landcover maps). Companies that settle in these locations are so-called "ubiquitous" businesses (often in international transport and logistics), which primarily depend on being within very easy reach of important European metropolises and, secondarily, on the availability of large tracts of cheap land. Resources and potentials specific to the Alps, e.g. commodities, labour, attractive scenery and a high quality of leisure activities, however, play a very marginal role (Wenzel 2011). Such companies are therefore much more closely associated with the European and global economy than with the Alpine space as such; they are located "along" rather than "in" the Alps.

3. Creation of commuter towns along the Alpine rim: From approximately 1980 onwards, commuter towns (living in the Alps, working in the extra-Alpine metropolis or its suburban belt) have grown up in regions along the Alpine rim, in the vicinity of large extra-Alpine metropolises, because the latter have been expanding and encroaching on the Alpine rim, and because of the high quality of the environment and leisure activities that renders regions along the Alpine rim highly attractive to residents. The outskirts of Nice, Geneva, Zurich, Munich, Vienna and Graz have already expanded to a significant degree, with the Alpine hinterland of Nice being most strongly affected (see map 3 in Perlik 2001). In the past, population growth in these regions has been particularly high (see map 26 in Bätzing 2003). Associated far-reaching functional and structural changes weaken these areas' Alpine connections, while their metropolitan association is strengthened.

4. Touristic urbanisation: Successful touristic development leads to a gradual urbanisation of tourist locations. As they initially tend to be small farming communities, it takes some time for them to reach the threshold number of residents (popuIation 10,000) to qualify as a "city" (Chamonix and Davos are probably the best-known examples). In 1990 there were only eighteen tourist centres in the Alps that could be classified as "cities" (Perlik 2001, p. 120), and they had a comparatively low number of residents (in 1990 a mere $2.9 \%$ of the total Alpine population). Hence, this form of urbanisation is the weakest of the four types of Alpine urbanisation. Again, the Alpine connections of these areas become increasingly fragile, while their association 
to visitors' source regions, including the adoption of rapidly-changing, post-modern leisure trends is intensified.

These four types of urbanisation have turned the Alps into an urbanised macro-region in terms of population and economy, but not in terms of surface area. According to Manfred Perlik's analyses based on 1990/91 census data (more recent data is not currently available), just under $62 \%$ of the total Alpine population lived in "urbanised zones"; more than $66 \%$ of all workplaces occupied $27 \%$ of the Alps' surface area (Perlik 2001, p. 80 and p. 122). By 2010 an estimated 66 to $68 \%$ of the Alpine population are likely to live in urbanised Alpine regions.

The disproportionately high growth in terms of population and economy since 1980 is due to the urbanisation of the centrally located and extremely accessible Alps. However, the development must be considered positive only to a very limited degree: in all four instances, it has been dependent on and induced by outside influences that have weakened the Alps' autonomy, and is intrinsically linked to extreme spatial contrasts between urbanised valley floors - plus a few tourist resorts in actual highmountain areas - and the depopulated mountains where urbanisation is not possible.

This "peripheral" form of urbanisation is likely to be typical of many rural, peripheral areas in Europe. Among the planet's high mountain ranges, however, the Alps are (still?) a singular case. Due to their location, no other high mountain ranges have been undergoing this kind of urbanisation alongside the disadvantage of their endogenous potentials.

\section{References}

Bätzing, W. (2003): Die Alpen. Geschichte und Zukunft einer europäischen Kulturlandschaft. 2. Auflage, C.H. Beck, München.

Borsdorf, A. \& M. Paal (eds.) (2000): Die "Alpine Stadt" zwischen lokaler Verankerung und globaler Vernetzung. Österreichische Akademie der Wissenschaften, Wien.

ESPON (2009): Deutschland in Europa. Ergebnisse des ESPON Programms 2006 aus deutscher Sicht. Bundesamt für Bauwesen und Raumordnung, Bonn.

Perlik, M. (2001): Alpenstädte - zwischen Metropolisation und neuer Eigenständigkeit. Institut für Geographie, Universität Bern, Bern.

Wenzel, M. (2011): Die Entwicklung der Gewerbegebiete entlang der A 12 im Tiroler Unterinntal unter Berücksichtigung der „Ubiquität“ der Betriebe. Erlangen (in progress). 


\title{
Alpine Fallows and Economic Perspectives of the Alps
}

\author{
René L. Frey
}

It was the year 2005 when an expression made waves in Switzerland: to many, "alpine Brache" (Alpine fallows, friche alpine) became the Unwort des Jahres - the ugliest expression of the year. It occurred in a study published by ETH Studio Basel and entitled "Switzerland: An Urban Portrait". Four prominent architects (Roger Diener, Jacques Herzog, Marcel Meili and Pierre de Meuron) and a sociologist (Christian Schmid) identified five types of space: metropolitan regions, city webs, quiet zones, Alpine resorts and Alpine fallows. "Alpine fallows are zones of degradation and slow decay" (p. 216) with slow but steady emigration due to their weak economic base and low added value (see also Schuler et al. 2007). Geographically speaking, Alpine fallows extend across the entire Swiss Alps, with pockets of international Alpine resorts such as St. Moritz, Davos or Zermatt that - for a few weeks each year - are transformed into veritable cities. According to the authors, an extensive and uninterrupted fallow zone has formed around the Gotthard, Switzerland's mythological centre, which they call the "Gotthard central fallow zone" (Zentralbrache Gotthard). Even though zones such as this have good transport links (e.g. motorways) to Swiss and European metropolitan regions, they remain peripheral. The authors argue that Alpine fallows lack the physical presence of an urban entity.

It is not surprising that Alpine residents responded to these controversial statements from ETH Studio Basel with displeasure and anger. Reactions ranged from charges that the authors were "arrogant city slickers" (various newspaper articles) to the assertion that "the Alpine fallow does not exist" (Lehmann et al. 2007, p. 76) and the claim that urban Switzerland was about to abandon its rural counterpart, in particular its peripheral Alpine areas (various newspaper articles). Nor were the authors blameless: they had wanted to provoke - and they did!

Some critics of the ETH Studio Basel report failed to read it exactly, taking the term "fallow" to mean something other than its original definition. In agriculture fallows are left to lie unused for some time (usually for a year) to allow the soil to recover. This is not inherently negative - nor is the term "industrial fallow" (also known as brownfield), which has been in circulation for a few decades to designate areas that have become obsolete and are lying empty until a new use has been found for them.

Perhaps "Alpine fallow" has also acquired a negative taste because the ETH Studio Basel study made but few suggestions regarding the direction in which development might occur. Residents in "Alpine fallows" felt abandoned. To be fair it must be said that the Urban Portrait refrains from making political recommendations, be it for these or for any other areas - it is strictly an analysis of the status quo.

However, the report does contain some thoughts on how Alpine fallows might develop. "An impartial look and re-assessment of structural development ... in Alpine fallows imposes itself. Decades of support provided to agriculture and infrastructure in the form of various kinds of transfer payment have been unable to stem the loss of dynamism and energy in these areas. The traditional conservation model no longer has a perspective; what is required is openness to other potential development pathways. In economic terms, retreating from cultivated landscapes and abandoning developed areas in the Alps does not necessarily appear as a loss on the balance sheet. Coming generations faced with land scarcity may find such areas to be welcome 
reserves for development. In the national land budget, fallow cultivated landscapes would thereby become an inner reserve" (p. 942).

Essentially, there are three "futures" for Alpine fallows - tourism, conservation or agriculture (see Frey 2008, pp. 110 ff.; Messerli 2007):

Hoping for tourist resorts: The Swiss Alpine space resembles a leopard skin with spots of economically successful tourist areas, or resorts. They are the paradigm of choice to those wishing to fight emigration and draining of Alpine fallows, their favourite solution being the implantation of tourist resorts.

The most spectacular and currently the most promising example of this strategy is Andermatt. For centuries this village situated near the Gotthard pass thrived on transiting traffic. When the Gotthard railway tunnel was built in the 1880 os and, some one hundred years later, the Gotthard road tunnel was opened, this source of income dried up. During and after World War Two the Swiss army with its numerous fortresses provided good incomes. But when the "réduit concept" - considering the Gotthard region as a core zone of military retreat - became obsolete at the end of the 2oth century and the army was downsized, Andermatt faced economic ruin. However, a few years ago, like a fabled Oriental prince, Egyptian tourist developer Samih Sawiris bought large tracts of land from the army to build a resort requiring investments of millions of euros. The diggers have just appeared on the scene. This is how quickly Alpine fallows can be converted if an incomer throws himself into the fray. In Andermatt these days, there is no talk of emigration - on the contrary.

Hoping for nature parks: Alpine areaswith littletouristic potential that are unable to sustain their resident population and constitute a financial burden on neighbouring areas can be turned into nature parks where commercial exploitation is banned. At Swiss federal level, legal provisions were made for this strategy in 2006. Depending on specific arrangements, there will be more or fewer employment opportunities. Accordingly, the need for complete absence of humans from nature parks may vary, at least in their strongly protected core zones. In extreme cases, park rangers will be the only people having jobs.

Hoping for agriculture: Agriculture is still the mainstay in Switzerland's Alpine space. However, its survival has been completely dependent on the Swiss government's financial and regulatory

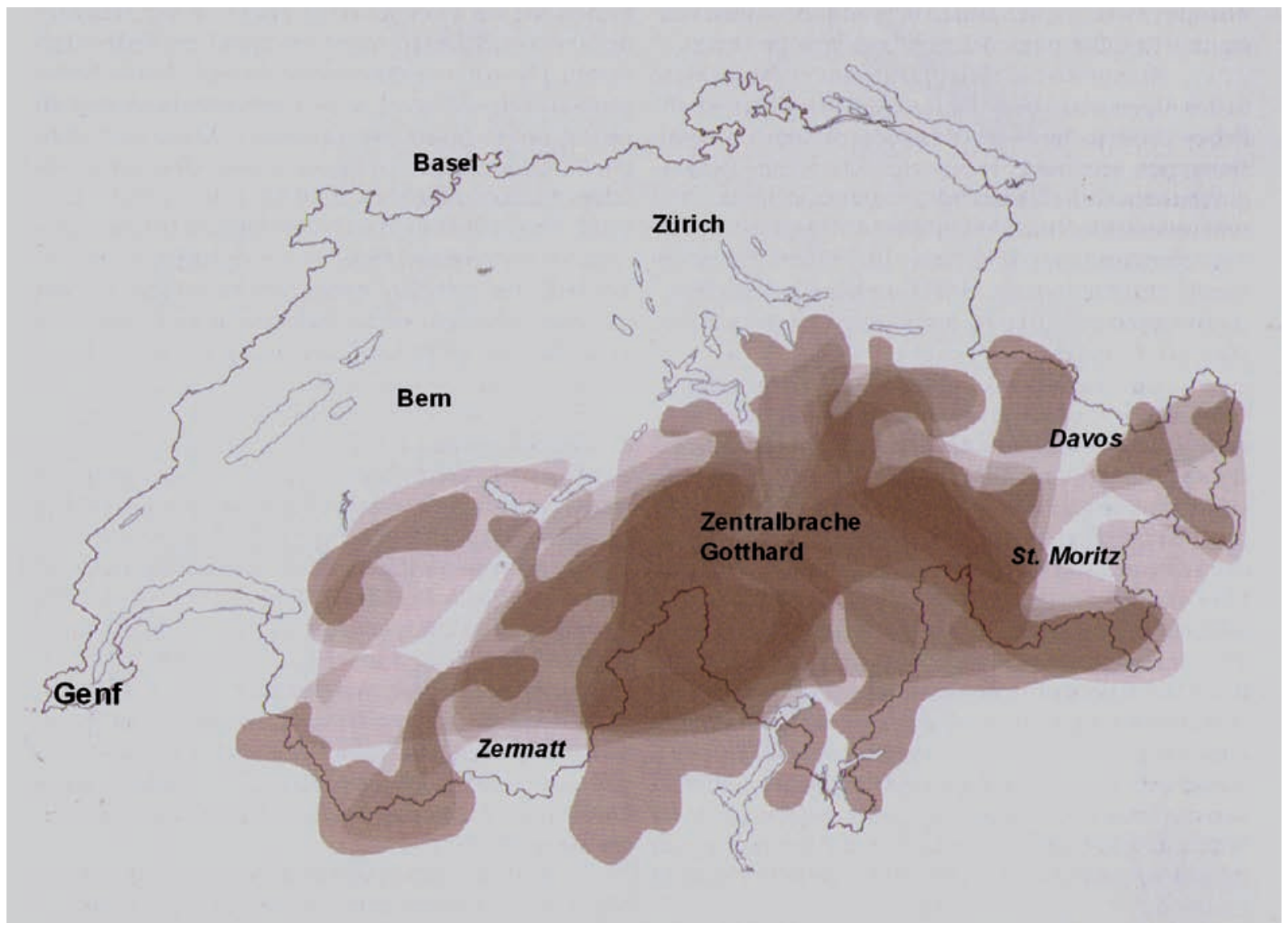

Fig.: Alpine Fallows in Switzerland.

Source: ETH Studio Basel - Diener R., J. Herzog, M. Meili et al. (2005), p. 217 (with additions). 
(i.e. protectionist) support. Considering international pressure, it is unlikely that this policy will be upheld indefinitely. It is scarcely sustainable in economic terms. The alternative consists in transforming product subsidies into contributions for ecologically managed areas. Many farmers and their associations, however, do not want to play the part of "landscape gardeners".

The above thoughts on the future of mountain and rural areas have been expressed in the context of a trend scenario. Top tourist destinations with excellent transport links to large metropolitan regions attract incomers; construction is thriving. The flip side of this economic success is a changing landscape and housing sprawl. So-called "low-potential areas", however, continue to lose their population - they remain fallows. Given the perfectly positive aspects of emigration in global economic terms and from the emigrants' perspective, it should not be a taboo any longer. However, Swiss politics are miles away from embracing this ideological shift (see, for example, ARE 2005).

The alternative scenario, "opening up", results in Switzerland becoming a metropolis that comprises the country's entire territory, including the Alps and rural areas in the pre-Alps, in the Jura and in the Mittelland. Partnerships are created between the various areas. Mountain populations do not receive money because they are economically deprived but because they render services (nature and landscape conservation, protection from natural hazards, hydro energy, etc.), which the urban populations appreciate and for which they are willing to pay a good price. However, the payers also expect Alpine areas to focus on their respective strengths: no longer everything everywhere and, more importantly, not everywhere the same things.

\section{References}

ARE Bundesamt für Raumentwicklung (2005): Raumentwicklungsbericht 2005. ARE, Bern.

ETH Studio Basel - Diener, R., J. Herzog, M. Meili et al. (2005): Die Schweiz - ein städtebauliches Portrait. Birkhäuser, Basel.

Frey, R. L. (2008): Starke Zentren - Starke Alpen. Wie sich die Städte und ländlichen Regionen der Schweiz langfristig entwickeln können. Verlag Neue Zürcher Zeitung, Zürich.

Lehmann, B., U. Steiger \& M. Weber (2007): Landschaften und Lebensräume der Alpen: Zwischen Wertschöpfung und Wertschätzung. Reflexionen zum Abschluss des Nationalen Forschungsprogramms 48. vdf, Zürich.

Messerli, P. (2007): Forschungs-LandschaftAlpen:Gesternheute - morgen. In: Lehmann et al. (2007): 78 ff.

Schuler, M., P. Dessemontet, Ch. Jemelin et al. (2007): Atlas des räumlichen Wandels der Schweiz (ed.: Bundesamt für Statistik, Neuchâtel). Verlag Neue Zürcher Zeitung, Zürich. 


\title{
Rural Areas - Challenges for Spatial Planning from the Austrian Perspective
}

\author{
Gerlind Weber
}

"It is difficult to predict, especially the future", said Wilhelm Busch with a humorous serenity. In conformity with Busch it is difficult to name the future challenges of rural areas for two main reasons: First, because the trends listed in the following are of course just a few among many and they are dynamically interlinked in a highly complex way, they reinforce each other, but partly also diminish each other. Secondly, in recent decades rural areas - not only in Austria - have developed very differently, so that at least a rough spatial differentiation is essential in order to come close to arguing accurately. Thus, on the one hand structurally strong rural spatial types are distinguished - such as two-seasonal tourist areas, rural areas along high-ranking traffic arteries or peri-urban areas. Rural areas with structural weaknesses on the other hand are found along the former Iron Curtain and in the inner-Alpine areas of Central and Eastern Austria.

The biggest challenges that will strongly determine rural development planning are

- climate change,

- the increased use of renewable energy,

- demographic change,

- the knowledge-based society and

- restricted financing capabilities.

These are briefly explained in the following.

\section{Climate Change}

Especially rural areas are required to bear the consequences of global warming: For example agriculture is affected in that it should contribute to climate protection by extensification to reduce greenhouse gas emissions. Farming is also expected to provide space for the prevention of natural hazards (such as for retention areas and drainage facilities in connection with the increased risk of flooding). Of course the forestry sector's contribution is also required, i.e. on the one hand maintaining the forest as an important carbon dioxide store and on the other hand supporting the conversion to renewable energy sources by providing wood.

All these named challenges are linked to additional spatial requirements on the (currently) undeveloped land. This must lead to a paradigm shift concerning how non-farming land use demands in rural areas are dealt with: Additional consumption of land for settlement and transport purposes must become a justified exception.

\section{Increased Use of Renewable Energy}

A basic shift in the management of traffic and settlement policy in rural areas is also necessary, because further expansion of the rural road network and the continued sprawl in rural areas are in conflict

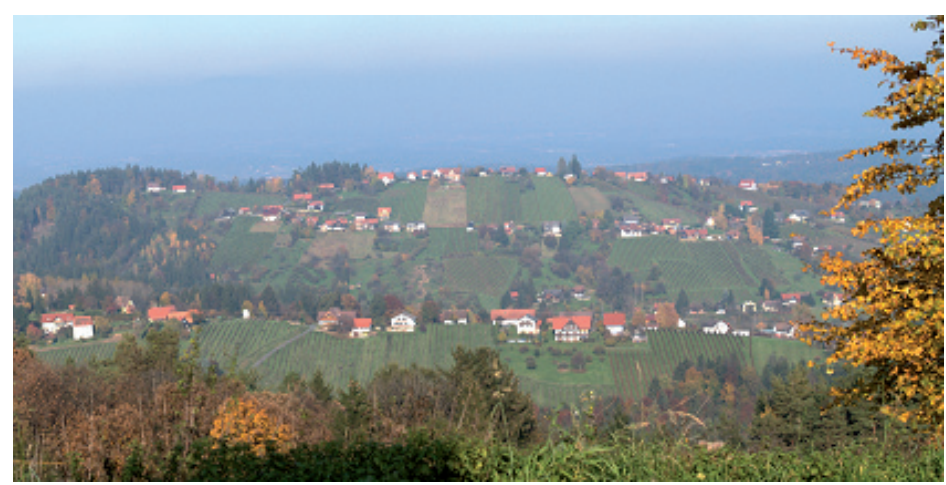

Fig. 1: Sprawl in Austrian Rural Areas.

Source: Institute of Spatial Planning and Rural Development (IRUB). 


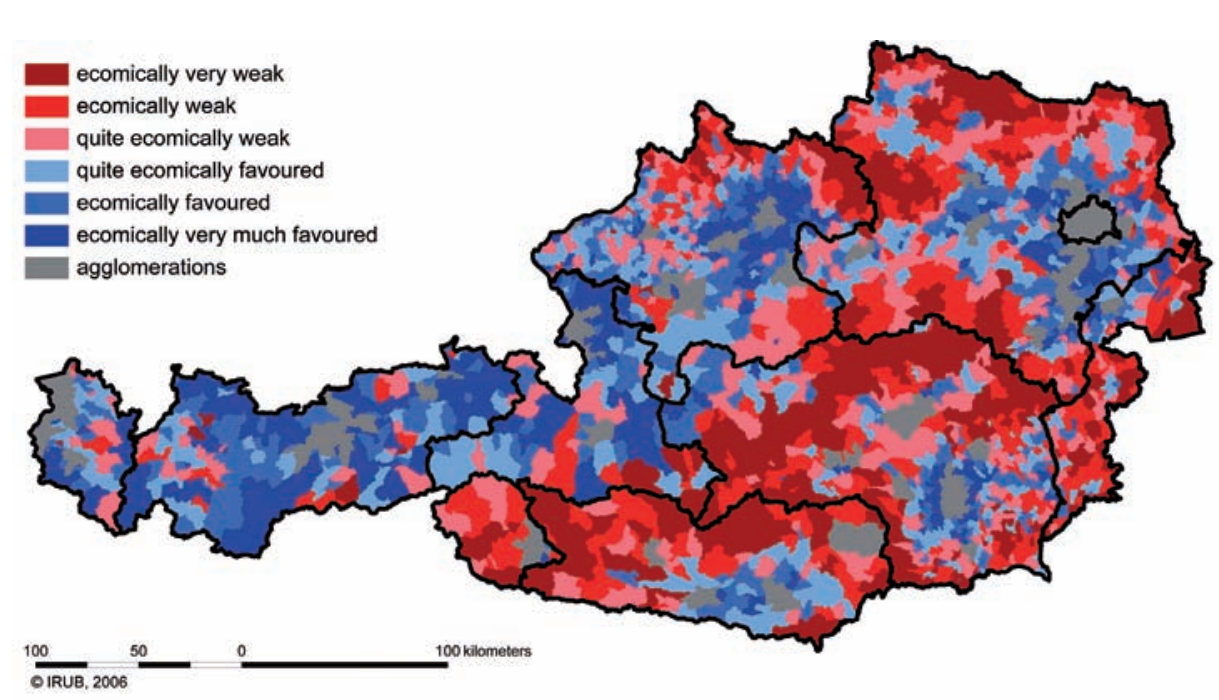

Fig. 2: Economically Weak and Economically Favoured Areas in Austria. Source: IRUB.

with the "20, 20, 20 - objective" of the European Union. Each additional kilometer of road and each additional building in the periphery means an increased consumption of energy, which contradicts the goal of reducing energy consumption by $20 \%$ (basis 1990) by 2020. A more and more extensive network of low-ranking roads which connect largescale buildings on the periphery of settlements that are home to fewer and fewer people are in conflict with the principle of effectiveness. Additionally strongly dispersed settlements are not suitable to be served by district heating pipes and are thus in conflict with the objective to increase the share of renewable energy sources by $20 \%$ by 2020 .

Therefore spatial planning is required to develop the tools for an effective energy planning and implementation (e.g. priority zones and exclusion zones for energy, optimizing the locations for distributed power systems, building "with" the sun etc.).

\section{Demographic Change}

Demographic change is a challenge especially for disadvantaged rural areas: In these areas there is a risk that the selective migration and the resulting disparity between working and young people on the one hand and people with nursing and care needs on the other will further increase the structural difficulties of these areas. One reason for this is that the funding system brings large financial disadvantages for municipalities which are affected by the decline of population numbers and reduced employment opportunities.

spatial planning is asked to "embrace" these shrinkage processes in areas in which the key indicators are shrinking and where no reversal of the trend can be observed. In addition planning strat- egies and planning tools have to be developed to accompany and actively shape this decline, rather than to (further) pursue growth hopes by a ruinous supply planning. A central question in this context is how to deal with building vacancies or excess capacity in both technical and social infrastructure.

\section{Knowledge-Based Society}

A mega trend that could hit the underdeveloped rural areas in particular is the trend towards a knowledge-based society. This means that investments in education and training compared to investments in technical infrastructure facilities in the regional economic competition for people and jobs are becoming a decisive location factor (assuming a minimum accessibility). It is assumed that this trend towards a knowledge-based society will strengthen especially central areas. Rural areas in contrast have a very limited capacity to keep the well trained and educated on site. These people follow their workplaces less and less, but choose their work and living place themselves.

Spatial planning needs to explore in which ways rural areas can participate in the knowledge-based society. One consequence of the knowledge society is, however, that the well-trained and educated actively want to participate in establishing policies regarding their living environment. Accordingly, the scope for Regional Governance needs to be explored and used by the respective planning authorities.

\section{Restricted Financing Capabilities}

The economic and financial crisis shows that a growing number of rural communities are highly indebted. For many communities the gap is rising 


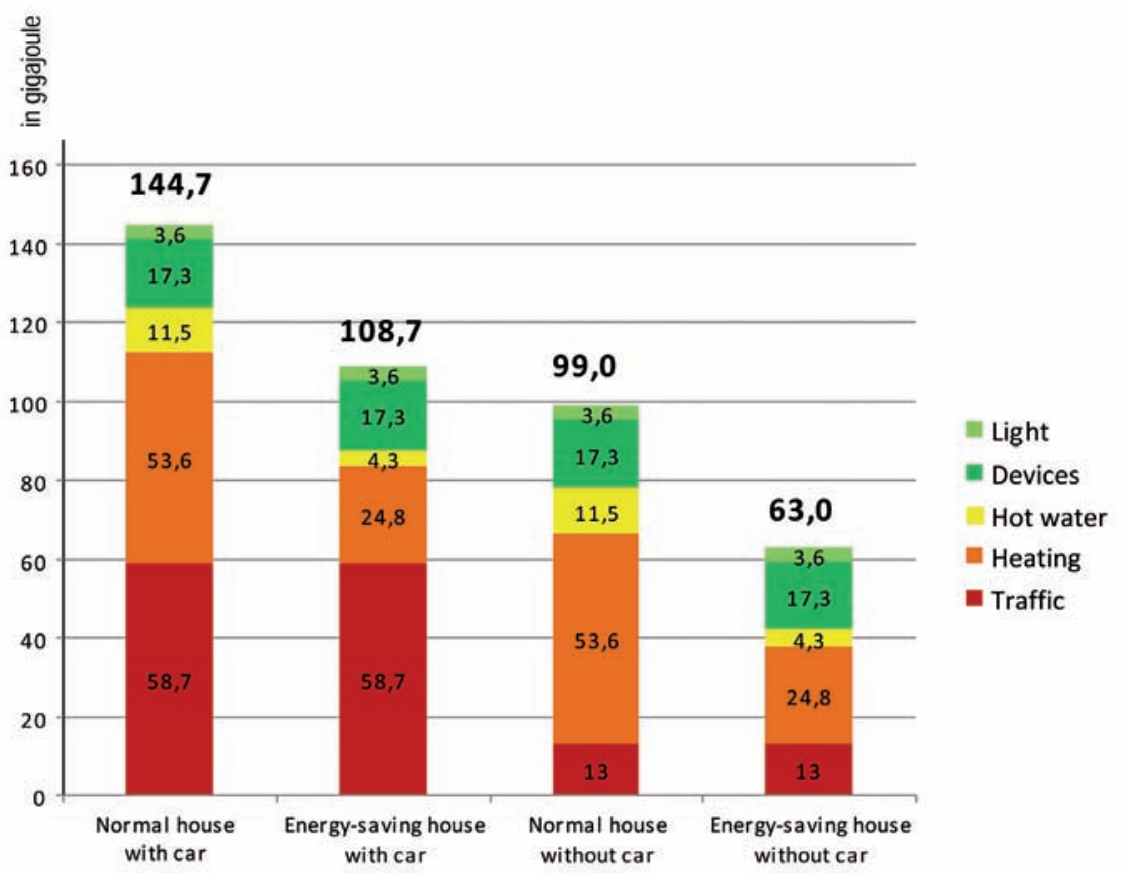

Fig. 3: Households without a car consume much less energy. Source: Verkehrsclub Österreich (VCÖ) 2007.

between decreasing revenues from ongoing population and job loss on the one hand and increasing expenditures on the other hand through growing social services (kindergartens, care for the elderly) but also through building more and more infrastructure networks (water supply, roads, sewer).

This results in the fact that not expansion, but rather the rebuilding and possibly even the dismantling of settlements and transport areas should occur on the agenda of spatial planning for rural areas. This also means that the focus needs to be put from the exterior development towards the "management" and the adaptation of the settlements. In addition, the funds need to be less committed to the "hardware" (buildings, technical infrastructure) than to the "software" (care, education and training, atmospheric and organizational improvements).

\section{References}

Academy of Spatial Research and Federal Planning (ARL) (2010): Regional Policy in the Light of Economic and Financial Crisis. Position Paper Nr. 82.

Österreichisches Institut für Raumplanung (ÖIR) (2008): Infrastructure Costs of Settlement Expansion of Existing Pipeline Networks. Final Report.

Fromhold-Eisebith, M. (2009): The "Knowledge Region" as a Chance of Creating a New, Sustainable Paradigm of Regional Development. 


\title{
Workshops
}

\section{1/1 Traditional and Innovative Forms of Migration - Sustainable Future for the Alps?}

\author{
Presentation: Manfred Perlik \\ Input: Martin Camenisch, Roland Löffler
}

\section{Concept}

The Alps are surrounded by a fringe of economically strong peri-Alpine metropolitan areas which reach with their peri-urban parts deep into the Alps. They integrate also sparsely populated regions up to the main ridge if these places offer attractive landscapes and easy access. This may be estimated as a new process: metropolitan areas are no longer restricted to their economic productive function. They integrate also recreative premium dwelling and leisure functions within an enlarged sphere of influence and use them as assets in the global competition to attract highly qualified people for their top ranked business service and research industries. There we have connective relations between Zurich and St. Moritz as well as Milan and St. Moritz by multilocal dwelling. But there are also relations between a working place in London City during the week, commuting by a low cost carrier and weekend dwelling in Chamonix with the family. This dimension of increased land use by multilocal habitats and the connecting infrastructure for mobility relativises the strategies and efforts to inhibit urban sprawl by "inner densification" of the metropolises and "non-development" strategies for the remaining rural regions.

These new processes sometimes are estimated as a second chance for the mountains. For a long time, migration flows went in the other direction: outmigration, caused by poverty, which in lucky cases resulted in a certain re-migration. New inhabitants, even if they do "recreational commuting", can bring purchase power into mountain regions. In a short term, these new migration processes might be successful. The question is whether the new metropolitan peripheries can profit in the long run by the function as leisure landscapes. Sometimes the new residences stand in competition to traditional tourism which developed over many decades to a mountain specific and embedded regional production

system. New economic functions seem to be more volatile than former ones. And the urban majority who uses the mountains temporarily might decide to go elsewhere while - at least at the moment - the metropolises are resilient because of their variety of face-to-face contacts, their specialized labor markets and their strong value chains in the nontourist service and knowledge-based industries.

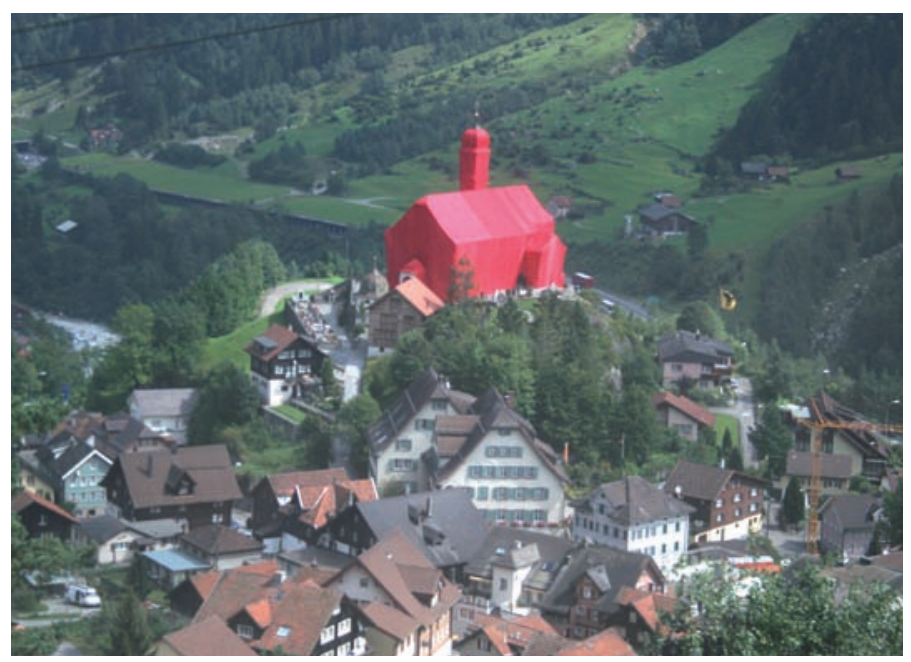

The Alpine Village in the Metropolitan Region: Municipality of Wassen in the Canton of Uri during the Events on the Occasion of the Gotthard Railway's 125th Anniversary in 2007.

\section{References}

Löffler, R. \& E. Steinicke (2007): Counterurbanization and Current Transformation in the Sierra Nevada. Geographical Review 97/1: 67-88.

Moss, L. A. G. (2006): The Amenity Migrants. Wallingford, Cambridge.

Schuler, M., M. Perlik \& N. Pasche (2004): Non-urbain, campagne ou périphérie - où se trouve l'espace rural aujourd'hui? Berne.

Université de Genève, projet de recherche: „Trajectoires résidentielles, identités territoriales et catégories géographiques." 


\title{
1/2 Traffic Between Metropolises and the Alps - do we Need to Search for New Systems and Strategies?
}

\author{
Presentation: Rudolf Juchelka \\ Input: Felix Günther, Thierry Louis
}

\section{Fundamentals and Framework}

Viewed from a traffic-related, economic and geographic perspective, the Alps are a unique singularity. Crucial for this is their location in the centre of Europe, particular topographic conditions, the Alpine ecosystem's high sensibility as well as the characteristics of very significant European traffic and development axes across the Alps.

To the traffic between Central and Southern Europe, the Alps have stood from the beginning of time for a natural barrier which could only be overcome very laboriously. As a result it was not until the beginning of the 19th century that the historic Alpine passes were developed and heavily used by horsedrawn carriages. This pass circulation was almost completely stopped by railway construction across the Alps toward the end of the 19th century. In 1867, the first train traversed the Alps. Without an elaborate tunnel construction the distance via the Brenner between Austria and Italy could be covered. Opposed to this, the construction of the Swiss Gotthard railway tunnel proved to be considerably more difficult. It took the most tedious manual labour to build countless bridges, overpasses and tunnels.

Resulting from the automobile's triumph the Alpine passes once more moved into the spotlight of transalpine traffic. But it was only the economic rise of the 1950s that resulted in a considerable increase of transit traffic. Responsible for this was not only the rise in commercial transportation but also the mass individualization of traffic by the automobile. Those in charge reacted to this growth of Alpine traffic by extending and creating new transregional transport infrastructure. Thus, beginning with the 1960s, new road tunnels were built which again were then further extended into autobahn tunnels due to ever rising traffic. In 1972 the Brenner route was handed over as the first continuous autobahn traversing the Alps. Eight years later the significant Gotthard tunnel was inaugurated in Switzerland. Besides the main routes there are further tunnels crossing the Alps. This way, they have become the best accessed high mountains.

The creation of a European domestic market implicated an enormous rise in commercial transportation, and passenger traffic has increased unchanged during recent years. The Alpine countries Switzerland and Austria are particularly affected since they are responsible for providing the infrastructural preconditions for handling these traffic flows. At the same time the Alps are - apart from their function as a transit route - an important destination for traffic, especially in the tourism and leisure sectors. Especially those metropolises located at the edge of the Alps such as Munich, Vienna, Zurich and Milan are, depending on the direction of traffic, major places of origin or destination, thus leading to congestion in the Alpine region. The overlay and concentration of these traffic flows leads to a number of problems which must be tackled on the one hand by extending the infrastructure - mentioned here are only large tunnel projects - and on the other hand by political means and controlling.

In a first step traffic policy reacted on the rise of transportation with further extending and building transit routes. Soon thereafter it was found that alternative concepts are inevitable for solving traffic problems. In order to counteract the growing traffic for the moment, a toll system as well as autobahn vignettes were introduced in Switzerland and Austria. However, the traffic problems cannot be solved by these two countries alone, since penalty measures in one country would lead to a shift of traffic to the neighbouring country. Therefore, in 1995 a European mutual consent, the Alpine Convention, was agreed upon by the bordering countries (Germany, France, Italy, Liechtenstein, Monaco, Austria, Switzerland and Slovenia). One emphasis of the Alpine Convention is traffic policy which concentrates on establishing railways as a more ecological carrier. In order to reach these goals, particularly the commercial transport crossing the Alps will be reorganized and limited with a number of measures. For one, higher dues ought to serve as an incentive to relocate commercial transportation onto railways. Furthermore, new construction will ensue, bundling and steering traffic flow anew.

A reduction of road transit traffic can only be achieved by offering adequate alternatives. Therefore, already in 1992 the Swiss decided upon a new Alpine railway transversal (NEAT). NEAT consists of a base tunnel at Gotthard $(57 \mathrm{~km}$, completion ca. 2014), at Lötschberg (34 km, completion 2007), the base Ceneri-tunnel and the Zimmerbergtunnel. This mammoth project is designed to facilitate an access for passenger transportation to the European high speed network. With NEAT, 
one hopes for a rationalization and thus higher attraction of the commercial railway use (shorter distances, less inclines requiring no more en route change of engines). Additionally, an entire bundle of measures by the Swiss transport authority will foster the shift of commercial transportation onto railways.

\section{Workshop}

Goals of the workshop are:

- To show the interrelationships between traffic flows and the problems of the Alpine region - To differentiate among the places of origin and destination of the traffic pertaining the Alps

- To demonstrate the different political views concerning an ideal Alpine traffic structure

- To discuss new and necessary strategies and concepts.

A specific emphasis is put on the urban systems bordering the Alps since they feature a unique meaning for traffic of origin as well as destination. Another focus lies on the importance of possible shifts in traffic onto the railway. Especially in this topical complex the influence of political restrictions and requirements becomes visible, which is partly assessed differently by the traffic and transport industries.
In the workshop this subject matter will be picked up by two input speakers. During subsequent discussion, possible developmental trends and scenarios for a sustainable traffic strategy in the Alpine region will be dealt with. The first short presentation will illustrate from the perspective of the Alpine Convention the occurring land use competition with view to traffic and thus take on the role of an introductory status report. The second presentation will demonstrate the necessity of strategic action from the perspective of space planning and simultaneously introduce the significance of strengthening rail traffic.

\section{References}

Fellendorf, M. (ed.) (2006): Verkehr im Alpenraum. Tagungsband der 5. Sommerakademie des Instituts für Straßen- und Verkehrswesen. Technische Universität Graz, Graz.

Fromhold-Eisebith, M. (2007): Konfliktfeld Alpentransit. Grenzen der Verkehrsentwicklung am Beispiel Österreichs und der Schweiz. Geographische Rundschau 59/5: 36-42.

Ruffini, F. et al. (eds.) (2006): Verkehr durch die Alpen: Entwicklungen, Auswirkungen, Perspektiven. Haupt Verlag, Bern.

Scholl, B. (2003): Integrierte Raum- und Verkehrsentwicklung im Alpenraum. Das Beispiel Schweiz. In: Raumordnung im Alpenraum. Akademie für Raumordnung und Landesplanung, Hannover: 47-53.

\title{
$1 / 3$ "And the winner is..." - on the Metropolisation of the Olympic Winter Games in the Alpine Space
}

\author{
Presentation: Thomas Busset \\ Input: Jean-Loup Chappelet
}

Traditionally, the International Olympic Committee (IOC) has delegated the organisation of the Winter Games to a town or a city. The Games' first edition was in Chamonix in 1924, the twenty-first one in Vancouver earlier this year. The range of Alpine host cities has consisted of three different types: mountain resorts (Chamonix 1924, St. Moritz 1928 and 1948, Garmisch-Partenkirchen 1936, Cortina d'Ampezzo 1956); a network of resorts around a hub or core city (Albertville 1992); and large cities (Innsbruck 1964 and 1976, Grenoble 1968, Turin 2006). Diachronically speaking, there was a first shift in scale paired with a move from the mountains to the valley floor, followed by a second move towards the surrounding plain. In this context, the preference given to Turin over Sion may also be interpreted as an underscoring of the Games' urban dimension, to the point where we are now looking at a fourth type of host venue, i.e. the metropolis.
In view of the massive size of today's Games' and huge requirements in terms of infrastructure (competitions, accommodation, transport, communication, etc.), only areas with significant economic, political and cultural resources now stand a good chance of success. While historically the IOC's choice has largely depended on contemporary contexts (such as the arrival of environmentalism), we would like to advance the hypothesis that, in the Alps, only regions that combine well-appointed mountain resorts with excellent connections to a regional centre will be able to successfully compete with nearby metropolises.

\section{Looking Forward to 2018 ...}

When it comes to Alpine locations, the choice of Turin as the organising city for the 2006 Winter Olympics was a benchmark in that, for the first 
time, the hub of events was located outside the actual mountain range. As such, this transfer constituted a rupture underscoring the defining role of infrastructure not related to sports (transport, hotels, TV studios, etc.) and highlights what is at stake both economically and politically as well as potential conflicts. In terms of the sports, events on ice seem to gain in appreciation over skiing, downhill skiing in particular. In historic terms, one could speak of a return to the metropolises as this is where the very first Olympic contests on ice were held before the creation of the actual Olympic Winter Games (1908 ice-skating in London; 1920 ice-skating and ice-hockey in Antwerp).

At first sight, the competition launched between Munich and Annecy is one between two fundamentally different projects, with the Bavarian metropo- lis and its Alpine hinterland vying for favour over the Savoyard tourist city that relies on a network of Alpine resorts. On their respective homepages, however, the gap between the two candidates has been closing. Munich emphasises its close ties with its hinterland and its partnership with GarmischPartenkirchen (where the skiing events would be held), while Annecy boasts the proximity of Geneva and the region's innovative capital. In fact, as they face the demands of the IOC, each candidate city has to rely on the same factors to compose the best bid. In view of the gigantic dimensions of today's Games, do cities and resorts in the Alps even stand a chance over competing metropolises? Who will be the winner at the end of the day? The workshop should provide some interesting answers.

\title{
1/4 Mountains and the Metropolitan Mind Urbanization, Imagination, and the Preservation of Alpine Nature
}

\author{
Presentation: Patrick Kupper \\ Input: Jon Mathieu, Tait Keller
}

In his seminal book "Wilderness and the American Mind" environmental historian Roderick Nash considered wilderness to be ultimately a subjective concept, "a state of mind". Mountains may seem to differ from wilderness, to be of another quality: more material, steadier and, thus, more objective. However, surveying the history of the past few centuries, Marjorie H. Nicolson discovered a sea change in how the Alps were perceived, for which she coined the phrase "mountain gloom and mountain glory". This change was widely shaped by travelers and climbers as well as writers, painters, and photographers who lived in metropolitan areas.

In the workshop we will explore the causes of the shifting imagination of the Alps in metropolitan areas and look for the consequences for both the Alpine region and the nearby metropolises. We will discuss the interconnections between the process of urbanization and the movement for the preservation of Alpine nature as well as for the development of the Alps as a mass tourist destination. In a first contribution Jon Mathieu critically reviews and complicates Nicolson's notion of a sea change in the public appreciation of the Alps and connects his historical insights to what is going on today. In a second input Tait Keller outlines how urban tourism brought urban issues to the Alps and how these encounters mutually shaped both the Alps and its urban visitors.

\begin{abstract}
References
Nash, R. (1967): Wilderness and the American Mind. Yale University Press, New Haven.

Nicolson, M. H. (1959): Mountain Gloom and Mountain Glory: The Development of the Aesthetics of the Infinite. Cornell University Press, Ithaca.
\end{abstract}

\section{Urbanization and Perceptions of the Alpine Area (Jon Mathieu)}

Partly based on differences in population density, urbanization in the Alpine area and in the surrounding lowlands proceeded for the most part in an uneven manner. The available data show that the absolute level of urbanization in the Alpine area increased considerably from the beginning of the modern period in the 16th century onwards, but in relative terms the area became more rural over time, since urbanization in the surrounding lowlands increased at a much higher speed, especially from the 18th and 19th century onwards. Against the background of this growing imbalance, the Alpine area was more likely to be seen as an "other" space by urban-based elites. It became more and more plausible to relate one space to "nature" and the other one to "culture" and "civilization", and then to develop a special interest for this exotic "nature". One indicator of the growing interest are published travel reports, which, in the Swiss case, 
increased more than eightfold during the second half of the 18th century. Thus in a short period the mountains of Switzerland, previously no object of public admiration, received a great deal of attention.

Yet this sea change in public attention needs qualification. Firstly, it was not a simple reversal from a totally negative to a totally positive view of the Alps, as the standard story suggests. Some components of "mountain glory" were present long before the Enlightenment and Romanticism gave them a new assessment and general prominence. Secondly, the Alpine discourse was not uniform in a territorial sense. Instead there were pronounced national and regional differences. During the Enlightenment, for example, the attention came mostly from Northern and Western Europe, and was focused on a relatively small Alpine territory between Lake Lucerne and Chamonix. Thirdly, the discourse was not only produced by lowland city-dwellers and scholars. Some positive representations of the Alps stemmed from Alpine elites who were in contact with the scholarly world, and eager to shed a positive light on their territory in a proto-national age.

What holds for earlier periods seems to be true for recent periods as well. Conservationist ideas existed long before the general "ecological turn" in the 1970 s gave the nature preservation a new degree of social attention and organization. The Alpine Convention that emerged out of this context around 1990 was promoted by lowland urban dwellers. However, inside forces were not absent, and a detailed analysis would reveal complex negotiation processes and constant shifts in appreciation. Again, national and regional contexts played a role. In Switzerland, for example, the official area for the application of the Convention was generally restricted, whereas Bavaria trebled its "Alpine" territory (in the new contractual sense) as compared to earlier conceptions. Now it extends practically to the outskirts of Munich.

\section{References}

Bätzing, W. (1993): Der sozio-ökonomische Strukturwandel des Alpenraumes im 20. Jahrhundert. Eine Analyse von „Entwicklungstypen“ auf Gemeinde-Ebene im Kontext der europäischen Tertiarisierung. Geographisches Institut der Universität Bern, Bern.

Mathieu, J. (2009): History of the Alps 1500-1900. Environment, Development and Society. West Virginia University Press.

Mathieu, J. \& S. Boscani Leoni (eds.) (2005): Die Alpen! Zur europäischen Wahrnehmungsgeschichte seit der Renaissance / Les Alpes! Pour une histoire de la perception européenne depuis la Renaissance. Lang, Bern.

\section{Where Sunday Lasts Forever: Urban Tourists in the Eastern Alps (Tait Keller)}

As the industrial revolution spread from Great Britain to the continent, the Alps gripped the imaginations of many urban Europeans. Between 1850 and 1890, climbers conquered most of the major Alpine peaks, and the growth of national Alpine clubs, such as the German and Austrian Alpine Association, accompanied the opening of the mountains. With close to 90,000 members in nearly 400 chapters, the German and Austrian Alpine Association was the largest climbing club in Europe in the early zoth century. It cleared trails, built huts, designed maps, published travel journals, and trained tour guides; it opened the mountains to a broader public beyond mountain climbers. The club's membership comprised primarily urban and middleclass men, people with time and money.

The significance of the organization extended beyond making the Alps accessible to men of leisure. The Alpine Association defined a thoroughly bourgeois perception of the mountain landscape. For most members, the mountains represented an escape from banal, urban lives. In the age of industry, the Alpine world offered relief from life's demands and freedom from the pressures of civilization. The mountains formed a seductive, natural antithesis to the growing cityscapes across Germany and Austria.

Tension, however, shaped the Eastern Alps. Technology and tourism inscribed the pressures of modernization on the palisades. For those tired of crowded cities, lonely crags once offered solitary joy. But by the early 2oth century, the Alps attracted millions of visitors per year. While wanderers in the mountains sought relief from city life, they brought the urban world with them. City-dwellers relied on industry for their flight from modernity. Machinery migrated to the high places. Massive construction projects carved the mountainside with roads and railways, altering the Alpine aesthetic.

Landscape preservation movements emerged from the Alpine Association, highlighting anxieties about the pace and scope of mass-tourism. These urban-initiated conservation groups saw the Alps as the last refuges of a wild and untamed nature, a world to be preserved. Yet the mountains were hardly a pristine realm. The high places had felt the human touch for centuries. Generations of dairy farmers had cultivated the Alpine pastures. Through their preservation efforts, Alpine enthusiasts from the city also civilized the mountains by attempting to protect something that never existed in the first place.

Frictions intensified as total visitors to the Eastern Alps reached record numbers in the interwar years. As Alpine tourism experienced explosive growth it 
became increasingly politicized. Dissension arose within the Alpine Association between those who wanted a social hiking club and those who desired an exclusive mountain climbing club. Concerns surrounding tourism's environmental impact and who could join the club divided the membership. The Alps were, in many ways, a fractured landscape.

With their "eternal presence" and "almighty strength", the jagged edges of civilization promised relief from political machinations and cultural despair in the early 2oth century. Imposing heights seemed to offer a firm foundation and sense of security, something that many urbanites found lacking on the slippery slopes of modern life. But with these urban tourists came urban issues. Today, the Alps number among the world's most popular tourist destinations with over five hundred million overnight visitors per year. These adventurers still shape the Alps as much as the Alps shaped them.

\section{References}

Der Bergsteiger.

Zeitschrift und Mitteilungen des Deutschen und Österreichischen Alpenvereins.

Günther, D. (1998): Alpine Quergänge: Kulturgeschichte des Bürgerlichen Alpinismus, 1870-1930. Campus, Frankfurt. Kariel, H. G. \& P. E. Kariel (1982): Socio-Cultural Impacts of Tourism: An Example of the Austrian Alps. Geografiska Annaler. Series B, Human Geography 64. 
Interactions Metropolises - Alps | Workshops 